\title{
Lumbar Intraosseous Schwannoma: Case Report and Review of the Literature
}

\section{Lomber Intraosseöz Şıvanom: Olgu Sunumu ve Literatür Derlemesi}

\author{
Deyong SONG ${ }^{1}$, Zhong $\mathrm{CHEN}^{2}$, Dewei SONG${ }^{3}$, Zaixue $\mathrm{LI}^{4}$ \\ ${ }^{1}$ Foshan Hospital of Traditional Chinese Medicine, Department of Spinal Surgery, Foshan City, China \\ ${ }^{2}$ Zhujiang Hospital of Southern Medical University, Department of Spinal Surgery, Guangzhou City, China \\ ${ }_{3}^{3}$ Mengyin County Hospital, Department of Minimally Invasive Pain Treatment, Linyi City, China \\ ${ }^{4}$ Shilong Affiliated Hospital of Southern Medical University, Department of Spinal Surgery, Dongguan City, China
}

Corresponding Author: Deyong SONG / E-mail: songdeyongss@126.com

\begin{abstract}
Intraosseous schwannomas of the mobile spine are extremely rare. To our knowledge, only 21 cases have been reported in the literature. In this report, we present a case of schwannoma involving the lumbar spine, with a review of the literature and discussion of this rare tumor. A 44-yearold male presented with a 3-year history of intermittent low back pain, with radiation into the right lower extremity during the last 2 years. Radiographs revealed an approximately $4 \times 4 \mathrm{~cm}$ irregular mass with marginal sclerosis located at the L5 vertebra, involving the right pedicle and extruding into the spinal canal. The tumor was resected completely and was confirmed as schwannoma by histological examination. At follow-up after 12 months, the patient was free of pain and with no recurrence. Despite its low incidence, intraosseous schwannomas should be considered as the differential diagnosis of an extradural mass involving the vertebrae. Surgery is the preferred treatment method and usually carries a good prognosis.
\end{abstract}

KEYWORDS: Intraosseous schwannoma, Lumbar vertebra, Surgery

\section{öz}

Hareketli omurganın intraosseöz şıvanomları son derece nadirdir. Bildiğimiz kadarıyla literatürde sadece 21 olgu bildirilmiştir. Bu raporda bir literatür derlemesi ile birlikte lomber omurgayla ilgili bir şıvanom olgusu sunuyor ve bu nadir tümörü tartışıyoruz. 44 yaşında bir erkek hasta 3 yıldır devam eden ve son 2 yıldır sağ alt ekstremiteye yayılan aralıklı bel ağrısı öyküsüyle geldi. Radyografiler L5 vertebrada sağ pedikülü tutan ve spinal kanal içine ekstrüzyon yapan, marjinal sklerozlu yaklaşık $4 \times 4 \mathrm{~cm}$ irregüler kitle gösterdi. Tümör rezeksiyonla tamamen çıkarıldı ve histolojik incelemede şıvanom olduğu doğrulandı. 12 aylık takipte hastada ağıı veya nüks yoktu. Düşük insidansına rağmen intraosseöz şıvanomlar vertebraları tutan ekstradural kitlelerin ayırıcı tanısında dikkate alınmalıdır. Tercih edilen tedavi yöntemi cerrahidir ve prognoz genellikle iyidir.

ANAHTAR SÖZCÜKLER: İntraosseöz şıvanom, Lomber vertebra, Cerrahi

\section{INTRODUCTION}

Schwannomas are most frequent extramedullary, intradural spinal tumors arising from the nerve sheath cells. Intraosseous schwannomas are rare benign tumors that account for less than $0.2 \%$ of primary bone tumors (9). They most commonly occur in the mandible and sacrum (13). Vertebral involvement is extremely rare (4). We report a schwannoma involving the lumbar spine and present the clinical, radiological and histological findings, with a review of the literature and discussion of this rare tumor.

\section{CASE REPORT}

A 44-year-old male presented with a 3-year history of intermittent low back pain, with radiation into the right lower extremity during the last 2 years. Over the recent few weeks his pain increased gradually and felt numbness of the medial aspect of the right foot. He had no previous trauma and medical problems. On examination there was local pain elicited by percussion of lumbar spine. The range of lumbar spinal motion was decreased, especially with regard to the flexion of the lumbar spine. The straight leg test was limited to $45^{\circ}$ on the right side. Motor strength of lower limbs was normal, patellar and Achilles tendon reflexes were equal and symmetrical, but he showed paresthesia on the right $L 5$ sensory dermatome. Computed tomography (CT) showed an approximately $4 \times 4 \mathrm{~cm}$ irregular mass with marginal sclerosis located at the $L 5$ vertebra, involving the right pedicle with posterior protrusion compressing the thecal sac (Figure 1A). It also revealed pars defects at L5.The mass was hypointense on T1-weighted images and hyperintensive on T2-weighted images (Figure 1B, C). Mild irregular enhancement was revealed on contrast-enhanced T1-weighted images after the administration of gadolinium (Figure 1D).

The patient was operated via a posterior approach. After L5 laminectomy, a well-encapsulated mass was found. The tumor mass was gray-white and avascular with a clear plane of 
cleavage from the surrounding tissues. No nerves in relation to the tumor could be identified. Biopsy was taken for frozen sectioning and the diagnosis was confirmed as schwannoma without any malignant features. The mass extruding into the spinal canal was separated and excised. The remaining tumor inside the L5 vertebral body was carefully removed using curettes. After excising the entire tumor, transpedicular screws and intervertebral bone fusion were applied to give spine stability on L4 to S1.
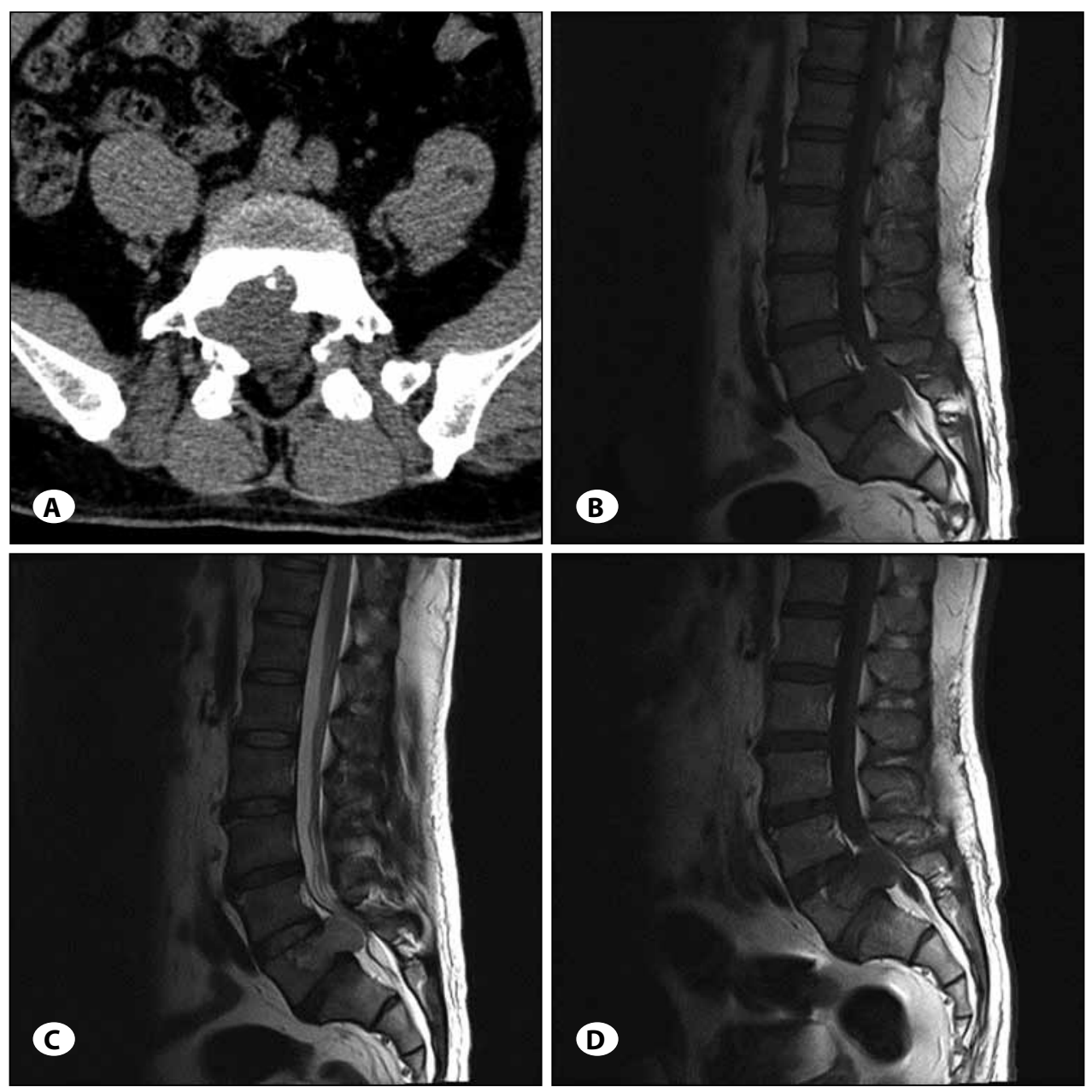

Figure 1: A) Axial CT showing lytic changes in the L5 vertebra and right pedicle with intraspinal extension. Isthmic spondylolysis of $\mathrm{L} 5$ can also be seen. B) MR showing the lesion is hypointense on T1-weighted, C) heterointense on T2-weighted and $\mathbf{D})$ demonstrating mild irregular enhancement on postgadolinium T1-weighted images.
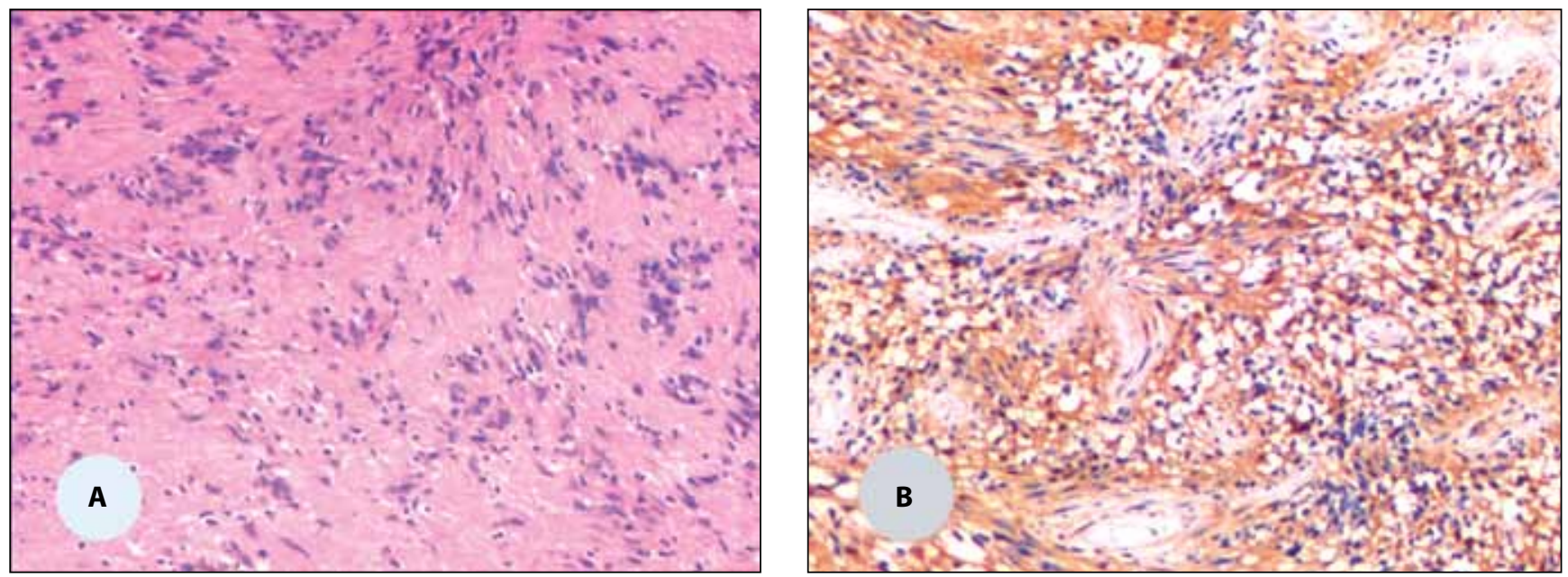

Figure 2: A) Photomicrograph of the tumor specimen reveals hypocellular areas (Antoni A) and hypercellular areas (Antoni B) (H\&E, original magnification $\times 100$ ). B) Immunohistochemical studies for S100 protein is diffusely positive. 
The histological examination of the lesion showed Antoni $A$ and $B$ areas with hypercelular, pallisaded cells alternating with hypocelular stroma (Figure 2A). Immunohistochemical testing for $\$ 100$ protein was diffusely positive, whereas glial fibrillary acidic protein was negative (Figure 2B).

The postoperative course was uneventful and the patient was free of preoperative complaints with no neurological deficit. At the latest one-year follow-up, he was asymptomatic. X-rays showed sound fusion and appearance (Figure 3A, B).

\section{DISCUSSION}

Schwannomas are the most frequent extramedullary, intradural spinal tumors, accounting for up to $25 \%$ of all intradural spinal cord tumors $(2,8)$. However, intraosseous schwannomas are rare benign neoplasms that account for less than $0.2 \%$ of primary bone tumors (9). They are most commonly seen in the third to fourth decade of life, and there is no gender predilection $(6,15)$. The most frequent sites for intraosseous schwannomas are in the mandible and sacrum, other reported sites include ulna, humerus, femur,tibia, ribs, patella, scapula, maxilla, the small bones of the hands and vertebral bodies $(3-5,7,17)$. The first case of intraosseous schwannoma was reported by Dickson in 1971 (7). Only 21 cases of intraosseous schwannoma in the mobile spine have been reported so far. Among these 21 cases, the male-to female ratio was 13:8. The age of the patients ranged from 10 to 65 years. Nine cases were in the cervical spine, six cases in the lumbar and six cases in the thoracic spine (Table I).

Three mechanisms have been postulated by which intraosseous schwannoma arises: (1) extraosseous tumor causing erosion of the bone, (2) tumor arising centrally within the bone, (3) tumor arising within the nutrient canal and growing in a dumbbell configuration $(6,11,14)$. In our case, like majority of reported cases, the exact origin of the tumor could not be identified. The surgical findings indicated that part of the tumor was extraosseous and we speculate that the third mechanism mentioned above was the probable pattern of occurrence. Sherman (16) observed nerve fibres existing in the marrow of the vertebra. However, most of them appeared to be non-myelinated and myelinated fibres were rare. This explains why intraosseous schwannomas rare occur in the vertebral body. Intraosseous schwannomas generally involve the anterior column of the spine. The tumor's chronic pressure and erosion on the vertebral body and the pedicle can result in scalloping of the vertebra, pedicle erosion and widening of the foramen; however, involvement of the posterior column has also been reported (12).

The radiological findings of intraosseous schwannoma are non specific. It usually appears as a lytic defect with cortical
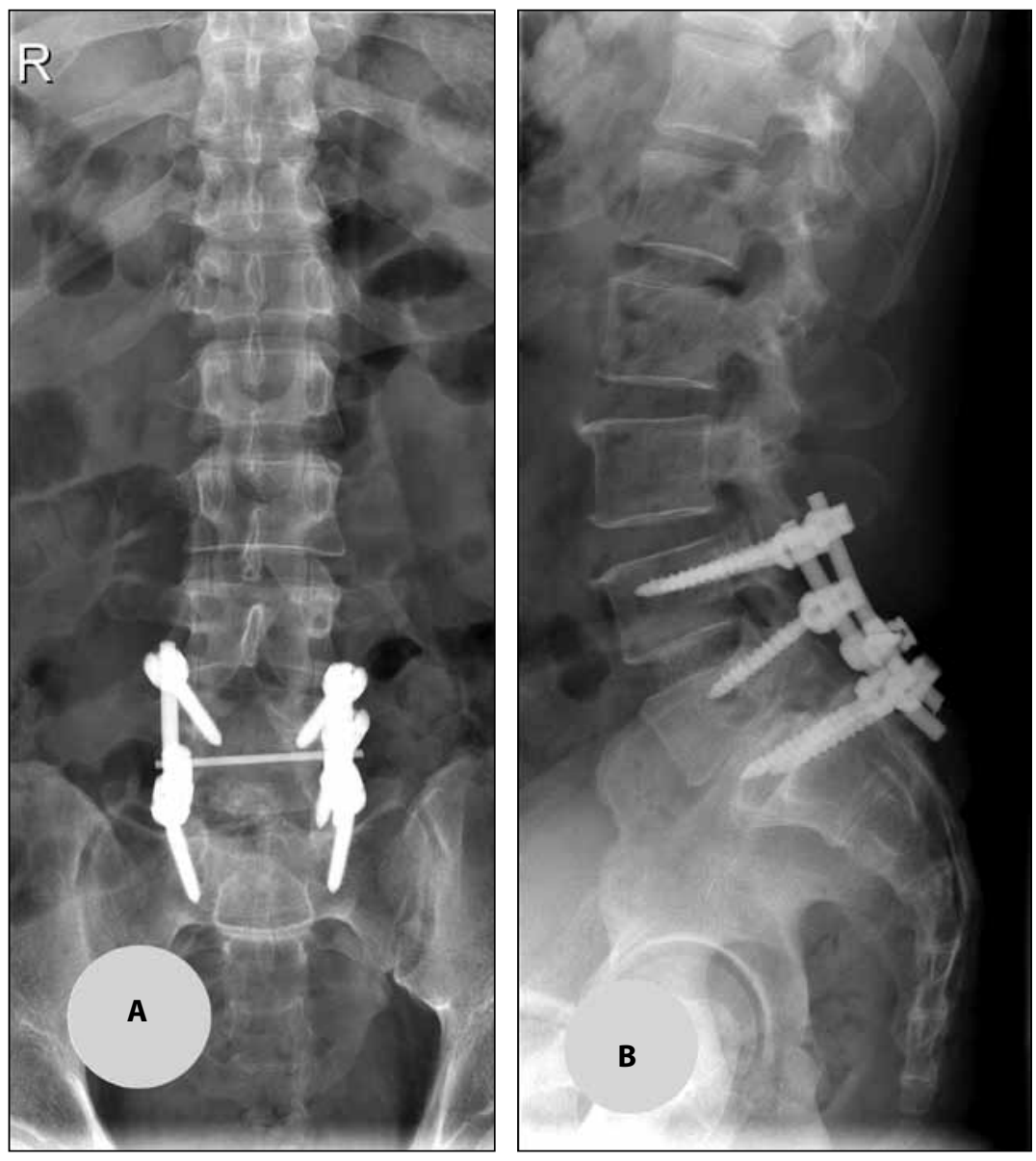

Figure 3: A) Anteroposterior and B) lateral postoperative radiographs showing good bony fusion. 
Table I: Previously Published Reports of Intraosseous Schwannoma in the Vertebrae (Excluding Sacrum)

\begin{tabular}{|c|c|c|c|c|c|c|c|c|c|}
\hline No & Year & Series & $\begin{array}{l}\text { Agel } \\
\text { Sex }\end{array}$ & Origin & Level & Resection & Pathology & Prognosis & Symptoms \\
\hline 1 & 1971 & Dickson & $51 / F$ & - & L3 & complete & benign & $\begin{array}{l}2 \text { years no } \\
\text { recurrence }\end{array}$ & $\begin{array}{l}\text { pain in bilateral lower } \\
\text { limbs }\end{array}$ \\
\hline 2 & 1975 & Polkey & $34 / F$ & - & $\begin{array}{l}\mathrm{C} 6 \\
\mathrm{C} 7\end{array}$ & complete & benign & - & $\begin{array}{l}\text { pain and weakness of } \\
\text { limbs }\end{array}$ \\
\hline 3 & 1988 & Naidu & $50 / \mathrm{M}$ & - & $\begin{array}{l}\mathrm{C} 3 \\
\mathrm{C} 4\end{array}$ & complete & benign & - & $\begin{array}{l}\text { burning paresthesias and } \\
\text { progressive weakness of } \\
\text { limbs }\end{array}$ \\
\hline 4 & 1997 & Nooraie & $46 / M$ & - & $\mathrm{T} 12$ & complete & benign & $\begin{array}{l}1.5 \text { years no } \\
\text { recurrence }\end{array}$ & $\begin{array}{l}\text { burst fracture caused by } \\
\text { trauma }\end{array}$ \\
\hline 5 & 1998 & Chang & $58 / M$ & - & $\begin{array}{l}\text { L4, } \\
\text { L5 }\end{array}$ & complete & $\begin{array}{c}\text { ancient } \\
\text { schwannoma }\end{array}$ & - & $\begin{array}{l}\text { pain and numbness of } \\
\text { lower extremities }\end{array}$ \\
\hline 6 & 2000 & Ramasamy & $37 / M$ & - & $\mathrm{T} 12$ & complete & $\begin{array}{l}\text { Schwannoma } \\
\text { with } \\
\text { proliferation }\end{array}$ & $\begin{array}{l}1.5 \text { years no } \\
\text { recurrence }\end{array}$ & $\begin{array}{c}\text { back pain, weakness } \\
\text { and numbness of lower } \\
\text { extremities }\end{array}$ \\
\hline 7 & 2001 & Schreuder & $38 / F$ & - & $\mathrm{C} 6$ & complete & benign & $\begin{array}{l}4 \text { years no } \\
\text { recurrence }\end{array}$ & $\begin{array}{l}\text { neck pain,paraesthesia of } \\
\text { right scapula }\end{array}$ \\
\hline 8 & 2001 & Inoka & $9 / F$ & $\begin{array}{l}\text { T10 } \\
\text { root }\end{array}$ & $\mathrm{T} 10$ & complete & benign & $\begin{array}{l}1 \text { year no } \\
\text { recurrence }\end{array}$ & $\begin{array}{l}\text { nontender distention of } \\
\text { the back }\end{array}$ \\
\hline 9 & 2001 & Inoka & $39 / M$ & - & L5 & operated & benign & $\begin{array}{l}3 \text { years no } \\
\text { recurrence }\end{array}$ & lumbar pain \\
\hline 10 & 2005 & Nannapaneni & $42 / M$ & - & C5 & complete & $\begin{array}{c}\text { ancient } \\
\text { schwannoma }\end{array}$ & $\begin{array}{l}1.5 \text { years no } \\
\text { recurrence }\end{array}$ & asymptomatic \\
\hline 11 & 2005 & Gupta & $30 / F$ & - & L2 & complete & benign & $\begin{array}{l}5 \text { months no } \\
\text { recurrence }\end{array}$ & $\begin{array}{l}\text { back, weakness of lower } \\
\text { limbs }\end{array}$ \\
\hline 12 & 2006 & Singrakhia & $43 / \mathrm{M}$ & - & $\begin{array}{l}\mathrm{C} 3 \\
\mathrm{C} 4\end{array}$ & subtotal & benign & $\begin{array}{l}1 \text { year no } \\
\text { recurrence }\end{array}$ & $\begin{array}{l}\text { numbness and weakness } \\
\text { of right shoulder }\end{array}$ \\
\hline 13 & 2006 & Singrakhia & $45 / M$ & - & $\mathrm{C} 3$ & subtotal & benign & $\begin{array}{l}1 \text { year no } \\
\text { recurrence }\end{array}$ & $\begin{array}{l}\text { pain and weakness of } \\
\text { right upper limb }\end{array}$ \\
\hline 14 & 2007 & Choudry & $18 / \mathrm{M}$ & - & $\mathrm{T} 12$ & complete & benign & $\begin{array}{l}5 \text { years no } \\
\text { recurrence }\end{array}$ & $\begin{array}{c}\text { back pain, weakness both } \\
\text { lower extremities }\end{array}$ \\
\hline 15 & 2009 & Cetinkal & $55 / F$ & - & $\mathrm{T} 12$ & complete & benign & $\begin{array}{l}1 \text { year no } \\
\text { recurrence }\end{array}$ & $\begin{array}{c}\text { back pain, pain and } \\
\text { numbness of right lower } \\
\text { limb }\end{array}$ \\
\hline 16 & 2009 & Park & $46 / F$ & - & L4 & complete & $\begin{array}{c}\text { ancient } \\
\text { schwannoma }\end{array}$ & $\begin{array}{l}21 \text { months no } \\
\text { recurrence }\end{array}$ & $\begin{array}{l}\text { back pain, weakness in } \\
\text { both lower extremities }\end{array}$ \\
\hline 17 & 2010 & Mizutani & $44 / F$ & - & $\mathrm{C} 4$ & complete & benign & $\begin{array}{c}17 \text { months no } \\
\text { recurrence }\end{array}$ & asymptomatic \\
\hline 18 & 2011 & Peng & $44 / M$ & - & $\mathrm{C} 3$ & complete & $\begin{array}{c}\text { malignant } \\
\text { transformation }\end{array}$ & $\begin{array}{c}\text { Recurrence at } \\
2 \text { years }\end{array}$ & neck pain \\
\hline 19 & 2011 & Kojima & $60 / M$ & - & T9 & complete & benign & $\begin{array}{l}2 \text { years no } \\
\text { recurrence }\end{array}$ & $\begin{array}{l}\text { back pain, weakness and } \\
\text { numbness of both lower } \\
\text { limbs }\end{array}$ \\
\hline 20 & 2012 & Youn & $65 / M$ & - & L2 & complete & $\begin{array}{c}\text { ancient } \\
\text { schwannoma }\end{array}$ & $\begin{array}{l}1 \text { year no } \\
\text { recurrence }\end{array}$ & $\begin{array}{c}\text { back pain, numbness } \\
\text { and paresthesias in right } \\
\text { lower limb }\end{array}$ \\
\hline 21 & 2013 & Mohanty & $10 / \mathrm{M}$ & - & $\mathrm{C} 4$ & complete & benign & $\begin{array}{c}10 \text { months no } \\
\text { recurrence }\end{array}$ & $\begin{array}{c}\text { painless mass, } \\
\text { dysphagia, stridor }\end{array}$ \\
\hline 22 & 2014 & $\begin{array}{l}\text { Present Case, } \\
\text { Song }\end{array}$ & $44 / M$ & - & L5 & complete & benign & $\begin{array}{l}1 \text { year no } \\
\text { recurrence }\end{array}$ & $\begin{array}{l}\text { back pain, right lower } \\
\text { extremity pain }\end{array}$ \\
\hline
\end{tabular}


erosion but without periosteal new bone formation, central calcification or ossification $(1,6)$. These tumors can be easily mistaken for giant cell tumor, solitary myeloma, aneurysmal bone cyst, chordoma, osteoblastoma or hemangioma $(13,17)$. On MR imaging, schwannomas are typically hypointense relative to the cord on $\mathrm{T1}$-weighted images and hyperintense on T2-weighted images. They may be heterogeneous on T2-weighted images with focal areas of hyperintensity and hypointensity corresponding to cyst formation, hemorrhage, dense cellularity, or collagen deposition (10). In our case the postcontrast T1-weighted images were atypical by virtue of the lack of contrast enhancement. We postulate that this was due to absent perfusion within the necrotic degeneration of the tumor.

Surgical excision is the preferred treatment option. Those tumors are usually well encapsulated without invasion of the surrounding structures, making complete resection possible. Complete resection was reported in 19/21 of the cases. Recurrence is rare following surgical resection. Among 19 reported cases for whom follow-up was available, 18 had no recurrence ranging from 5 months to 5 years, except one case recurrence with malignant transformation of a benign intraosseous schwannoma that was reported 2 years after the operation (Table I).

It is worth noting that it is important to carry out preoperative or intraoperative biopsy. This can help surgeons choose the appropriate treatment option. In our patient, the histopathological confirmation of benign schwannoma was obtained by intra-operative frozen section, and the tumor was therefore removed completely without damage to the surrounding tissues. Our present patient had both L5 vertebral tumor and isthmic spondylolysis. Surgical treatment of the isthmic spondylolysis was not necessary at that time. Considering that spondylolisthesis might occur after laminectomy and destruction of the vertebral body, internal fixation and bone graft union were performed from L4 to S1.

\section{CONCLUSION}

Intraosseous schwannomas are rare tumors and should be considered in the differential diagnosis of an extradural mass involving the vertebrae. Surgical excision is the preferred treatment option. Complete resection can be achieved and recurrence is uncommon.

\section{REFERENCES}

1. Agha FP, Lilienfeld RM: Roentgen features of osseous neurilemmoma. Radiology 102(2):325-326, 1972

2. Ahn DK, Park Hs, Choi DJ, Kim TW, Park SY: The surgical treatment for spinal intradural extramedullary tumors. Clin Orthop Surg 1:165-172, 2009
3. Barnowsky L, Dala R: Extradural schwannoma manifested as an expansile vertebral lesion. AJR Am J Roentgenol 159: 1352-1353, 1992

4. Chang CJ, Huang JS, Wang YC, Huang SH: Intraosseous schwannoma of the fourth lumbar vertebrae: Case report. Neurosurgery 43:1219-1222, 1998

5. Choudry Q, Younis F, Smith RB: Intraosseous schwannoma of D12 thoracic vertebra: Diagnosis and surgical management with 5-year follow-up. Eur Spine J 16(3):283-286, 2007

6. De la Monte SM, Dorfman HD, Chandra R, Malawer M: Intraosseous schwannoma: Histologic features, ultrastructure, and review of the literature. Hum Pathol 15:551-558, 1984

7. Dickson JH, WaltzTA, Fechner RE: Intraosseous neurilemmoma of the third lumbar vertebra. J Bone Joint Surg Am 53: 347-355, 1971

8. Engelhard $\mathrm{HH}$, Villano JL, Porter KR, Stewart AK, Barua M, Barker FG, Newton HB: Clinical presentation, histology, and treatment in 430 patients with primary tumors of the spinal cord, spinal meninges, or cauda equina. J Neurosurg Spine 13:67-77, 2010

9. Fawcett KJ, Dahlin DC: Neurilemmoma of bone. Am J Clin Pathol 47:759-766, 1976

10. Friedman DP, Tar taglino LM, Flanders AE: Intradural schwannomas of the spine: MR findings with emphasis on contrast-enhancement characteristics. AJR Am J Roentgenol 158:1347-1350, 1992

11. Gordon EJ: Solitary intraosseous neurilemmoma of the tibia review of intraosseous neurilemmoma and neurofibroma. Clin Orthop 117:271-282, 1976

12. Kojima M, Seichi A, Yamamuro K, Inoue H, Kimura A, Hoshino $\mathrm{Y}$ : Intraosseous schwannoma originating from the posterior column of the thoracic spine. Eur Spine J 20 suppl 2:S153S156, 2011

13. Mizutani A, Yokota N, Kawaji H, Yamaguchi-Okada $M$, Miyagawa T, Namba $\mathrm{H}$ : Intraosseous schwannoma of the cervical vertebral body: A case report and review of the literature. Br J Neurosurg 24(5):604-606, 2010

14. Samter TG, Dahlin DC: Neurilemmoma of bone. Report of 3 cases with review of the literature. Radiology 75:215-222, 1960

15. Sanado L, Ruiz JL, Laidler L, Polo M: Femoral intraosseous neurilemmoma. Arch Orthop Trauma Surg 110(4):212-213, 1991

16. Sherman SH: The nerve of bone. J Bone Joint Surg Am 45: 522-528, 1963

17. Singrakhia MD, Parmar $H$, Maheshwari M, Fehlings M: Cervical schwannoma presenting as an expansile vertebral body lesion, report of two cases with a technical note on the surgical management. Surg Neurol 66:192-196, 2006 